\title{
CLIMATE VARIATION, STRUCTURAL-DYNAMIC ORGANIZATION OF FORESTS AND FOREST MANAGEMENT: SOME ASPECTS OF FORESTS USE, THE BAIKAL REGION, RUSSIA
}

\author{
Alexander Sizykh ${ }^{1 *}$, Tatyana Konovalova ${ }^{2}$, Alexander Gritsenyuk ${ }^{3}$ \\ ${ }^{1 *}$ Siberian Institute of Plants Physiology and Biochemistry of RAS SB, 664033 Irkutsk, 132 Lermontova str., Russia; \\ ${ }^{2}$ Irkutsk State University, 664033, Irkutsk, 126 Ulan-Batorskay str., Russia; \\ ${ }^{3}$ V.R. Filippov Buryat State Academy of Agriculture, 670024, Ulan-Ude, 1 Pushkina str., Russia; \\ "Corresponding Author Alexander Sizykh, e-mail: alexander.sizykh@gmail.com;
}

Received May 2020; Accepted June 2020; Published July 2020;

DOI: https://doi.org/10.31407/ijees10.307

\begin{abstract}
On the background of climate dynamics during last decade, the Baikal Region manifests considerable changes in the whole biota structure. It is seen in the structural-dynamic organization, trends of forests development due to considerable variability of vertical and horizontal structures in the coenoses. Especially this is characteristic for the forests formation at the contact of different environments - at the boundary of zonal vegetation types and height belts in Pre-Baikal. Projects of protective forests in the basins of the rivers flowing into Lake Baikal in forests management for water protection and establishment of forests site under special protection within near-shore protective shelter belts excludes industrial forest cutting and limits other forms of forests use. Accounting of environment protection functions of forests at forests management and establishment of validity categories (not only for utility) will allow to stabilize hydroregimes and functioning of Lake Baikal basin' ecosystem in the whole.
\end{abstract}

Key words: climate variation, forest management, forest use, hydroregimes, Baikal region 